\title{
Investigation of the Effects of Biological Activity and Steeping Time of Four Different Black Teas Commercially Valuable in Turkey
}

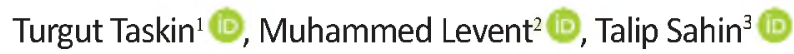 \\ ${ }^{1}$ Marmara University, Faculty of Pharmacy, Department of Pharmacognosy \\ ${ }^{2}$ Tamirhane Pharmacy \\ ${ }^{3}$ Marmara University, Faculty of Pharmacy, Department of Biochemistry \\ Correspondence Author: Turgut Taskin \\ E-mail:turguttaskin@marmara.edu.tr \\ Received: 22.01.2019 Accepted: 15.08.2019
}

\begin{abstract}
Objective: The aim of this study was to compare the phenolic, tannins contents and biological activities (antioxidant, anticholinesterase) of four different black teas commercially valuable in Turkey. Subsequently, to examine the effect of the steeping time on the chemical contents (phenolic and tannins contents) and biological activities of the samples.

Methods: The antioxidant activities of samples were examined by 2,2-diphenyl-1-picryl-hydrazyl (DPPH), cupric reducing antioxidant capacity (CUPRAC) and ferric reducing/antioxidant power (FRAP) methods. The amount of total phenolic and tannins contents contained in the samples was determined using the Folin-Ciocalteu reagent (FCR) method. In addition, the anticholinesterase activities of different samples were evaluated by Ellman method.

Results: According to the results obtained, filtered tea bag (FT) sample obtained after 5 min steeping exhibited stronger DPPH radical scavenging activity than other samples. In addition, it was found that powder ceylon tea (PCT) samples obtained after 60 min and 10 min steeping had the highest FRAP and CUPRAC values respectively. In this study, it was also determined that the PCT samples obtained after 5 min, 10 min, 15 min, and 30 min steeping contained higher phenolic and tannins contents than the other samples. In anticholinesterase experiment, powder tea (PT) sample obtained after 5 min steeping was found to have the strongest anticholinesterase activity.

Conclusion: As a result, it was determined that the amount of phenolic contents generally increased with the infusion time. It was also found that the antioxidant, anticholinesterase activities and tannins content of the tea samples did not show significant change due to the time of the infusion. Keywords: Black teas, antioxidant, anticholinesterase, steeping time
\end{abstract}

\section{INTRODUCTION}

Tea growing and consumption have been based on thousands of years ago. On a global level, tea was the second most commonly consumed drink which was prepared from systematically processed dried tea (Camellia sinensis L.) leaves by boiling in water (milk and/or sugar are added sometimes). Teas have been used in many countries for the treatment of infections and diseases. Tea leaves are rich in secondary metabolites such as phenolic antioxidants, proteins, amino acids, lipids, sugars, vitamin, fiber and minerals (1).

Polyphenolic compounds found in plants are important because they were responsible for biological activity. These compounds were known as potent antioxidants. Besides antioxidant activity, these compounds have antibacterial, anti-carcinogenic, anti-inflammatory, anti-viral, anti-allergic, estrogenic and immune-stimulating effects. In order to better define the potential health benefits of tea, it was important to determine the phenolic compounds in tea and the influences of infusion time on biological activity $(2-4)$. Steeping time was usually controlled in an experimental environment; however, it is generally known that brands recommend steeping time for 5-10 minutes or less but the Turkish people were prepared tea in different time (4).

Therefore, the aim of this study was to compare the phenolic, tannins contents and biological activities (antioxidant, anticholinesterase) of four different teas commercially valuable in Turkey. Subsequently, to examine the effect of the infusion time on the chemical contents (phenolic and tannins contents) and biological activities of the samples. This included Powder Tea (PT), Filtered Tea Bag (FT), Powder Ceylon Tea (PCT) and Goran Tee (Mevlana) (GT). Steeping times of 5-60 min were selected to represent realistic durations used by consumers in Turkey.

\section{METHODS}

\subsection{Samples and preparation of samples}

PT (Çaykur, Rize Turkey), FT (Doğuş, Rize, Turkey), PCT (Istikan Brand, Turkey), and GT (Goran TEE, Luxus-Mischung, Germany) samples were purchased from markets in Turkey (Table 1). Tea samples $(6 \mathrm{~g})$ were extracted with $150 \mathrm{~mL}$ of 
$\mathrm{H}_{2} \mathrm{O}$ at different time (5-60 min.) using infusion method. After certain steeping time $(5,10,15,30$ and $60 \mathrm{~min}$.) the extracts were filtrated then were concentrated by water bath (GFL, Germany).

Table 1. Characteristics of tea samples

\begin{tabular}{|l|l|l|l|}
\hline Sample identification & Common Name & $\begin{array}{l}\text { Scientific } \\
\text { Name }\end{array}$ & Type \\
\hline PT & Powder Tea & C. sinensis & Black Tea \\
\hline FT & Filtered tea bag & C. sinensis & Black Tea \\
\hline PCT & Powder Ceylon Tea & C. sinensis & Black Tea \\
\hline GT & Goran tee & C. sinensis & Black Tea \\
\hline
\end{tabular}

\subsection{Quantification of total phenolic contents}

The total phenolic contents of the samples were determined using the Folin-Ciocalteu reagent (FCR) method. Briefly, 5 $\mu \mathrm{L}$ extract was taken in the plate and $225 \mu \mathrm{L}$ of water was added. Then $5 \mu \mathrm{L}$ of Folin-Ciocalteu reagent (diluted 1/3 with distilled water) and $15 \mu \mathrm{L}$ of $2 \%$ sodium carbonate solution were added to the mixture. The mixture was allowed to stand at room temperature for 2 hours, and then absorbance was measured at $760 \mathrm{~nm}$ against the reference. The total phenolic contents in the extracts were given as mg gallic acid equivalents/g extract (5).

\subsection{Determination of tannins content}

The amount of tannin contained in the samples was determined by the Folin - Ciocalteu method(6). Briefly, 0.1 $\mathrm{mL}$ of the extracts was added to a volumetric flask $(10 \mathrm{~mL})$ containing $7.5 \mathrm{~mL}$ of distilled water and $0.5 \mathrm{~mL}$ of FolinCiocalteu reagent, $1 \mathrm{~mL}$ of $5 \% \mathrm{Na}_{2} \mathrm{CO}_{3}$ solution and dilute to $10 \mathrm{~mL}$ with distilled water. The mixture was shaken well and kept at room temperature for $30 \mathrm{~min}$. Then absorbance of mixture was measured against the blank at $725 \mathrm{~nm}$. The tannins content was expressed as $\mathrm{mg}$ tannic acid equivalents in milligram per gram of extract (mgTAE/ g extract).

\subsection{2,2-diphenyl-1-picryl-hydrazyl (DPPH) free radical scavenging activity}

The ability of free radical scavenging of samples was determined using the DPPH method. Briefly, $240 \mu \mathrm{L}$ of DPPH solution $(0.1 \mathrm{mM})$ was added to $10 \mu \mathrm{L}$ of extracts prepared at different concentrations $(5 \mathrm{mg} / \mathrm{mL}-0.5 \mathrm{mg} / \mathrm{mL}$ ). Then the mixture was allowed to stand at room temperature for $30 \mathrm{~min}$. The absorbance of the mixture was measured against the reference using a micro plate reader at $517 \mathrm{~nm}$. The experiment was repeated three times and the results obtained in the experiment were given as percent inhibition (\%) (7).

\subsection{Ferric reducing/antioxidant power (FRAP) assay}

The ability of ferric reducing of samples was evaluated using the FRAP method. Briefly, $190 \mu \mathrm{L}$ of FRAP reagent was mixed with $10 \mu \mathrm{L}$ of extract and after 4 min the absorbance of the mixture was measured against the reference at 593 $\mathrm{nm}$. The standard curve was prepared using $\mathrm{FeSO}_{4} \cdot 7 \mathrm{H}_{2} \mathrm{O}$ and FRAP values of the extracts were expressed as a $\mathrm{mM} \mathrm{Fe}^{2+} / \mathrm{mg}$ extract (8).

\subsection{Cupric reducing antioxidant capacity (CUPRAC) assay}

Cupric reducing antioxidant capacity (CUPRAC) method was used for evaluate the antioxidant capacity of samples. Briefly, $60 \mu \mathrm{L}$ each of $\mathrm{Cu}$ (II) (1.10-2 M), neocuproine ethanolic solution (7.3.10-3 M) and $1 \mathrm{M} \mathrm{NH} 4 \mathrm{Ac}$ buffer solution were mixed in plate. Extracts $60 \mu \mathrm{L}$ and $10 \mu \mathrm{L}$ pure EtOH were added to the initial mixture so as to make the final volume: $250 \mu \mathrm{L}$. The mixture was vortexed for $10 \mathrm{~s}$ and absorbance measurement was performed exactly after $60 \mathrm{~min}$ at $450 \mathrm{~nm}$ against a reagent blank. The CUPRAC values of samples were reported as trolox equivalents (mM trolox/mg extract) (9).

\subsection{Anticholinesterase activity of samples}

Inhibition of cholinesterases was evaluated using a 96-well microplate reader based on the method of Ellman et al., (1961) with some modifications. All reagent solutions (daily) were prepared using Tris- $\mathrm{HCl}$ buffer $(50 \mathrm{mM}, \mathrm{pH}$ 8.0). Briefly, $20 \mu \mathrm{L}$ of acetylcholinesterase (AChE) solution were mixed with $20 \mu \mathrm{L}$ of the sample and $40 \mu \mathrm{L}$ of Tris- $\mathrm{HCl}$ buffer and the mixture was left at room temperature $\left(25^{\circ} \mathrm{C}\right)$ for 10 minutes. Then, $20 \mu \mathrm{l}$ of acetylcholine iodide (ATChl) $(50 \mathrm{mM}$ ) was added the mixture and the mixture was incubated for $5 \mathrm{~min}$

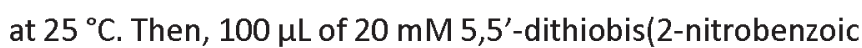
acid) (DTNB) (containing $1 \mathrm{M} \mathrm{NaCl}$ and $0.2 \mathrm{M} \mathrm{MgCl}_{2} .6 \mathrm{H}_{2} \mathrm{O}$ ) was added in the mixture and the absorbance of mixture was read at $412 \mathrm{~nm}$ against the reference. The experiments were performed in triplicate in each case. Galantamine was used as reference $(10)$.

\subsection{Statistical analysis}

The all experiments were done in triplicates and all data were shown as mean \pm SD. The data were analyzed by Graphpad Prism 5 program (Harvey Motulsky, La Jolla, USA). Statistical differences between the experimental groups were analyzed using one-way analysis of variance (ANOVA) followed by Tukey's Multiple Comparison test. Mean values were considered statistically significant when $p<0.05$. Patient consent: Not required patient consent for this study.

\section{RESULTS}

\subsection{Quantitative phytochemical analysis of samples}

Total tannins and total phenolic contents: The total phenolic, and tannins contents of samples were analyzed 
and presented in Table 2. When the amounts of phenolic and tannins content in the samples were compared, it was found that the PCT sample obtained after $5 \mathrm{~min}, 10 \mathrm{~min}, 15 \mathrm{~min}$, and 30 min steeping contained higher phenolic and tannins contents than the other samples. It was determined that the amount of phenolic contents in FT, GT and PT samples obtained after 60 min steeping increased with respect to the other minute but the amount of phenolic contents in the PCT sample did not change. In this study, it was found that steeping time did not cause a significant difference in the amount of tannins contained in samples.

Table 2. Total tannins and phenolic contents of tea samples

\begin{tabular}{|c|c|c|}
\hline Codes of samples & $\begin{array}{l}\text { Total phenolic } \\
\text { (mgGAE/g extract) }\end{array}$ & $\begin{array}{l}\text { Tannins (mgTA E/g } \\
\text { extract) }\end{array}$ \\
\hline \multicolumn{3}{|c|}{ After 5 min. steeping } \\
\hline $\mathrm{FT}$ & $75 \pm 0.023^{a}$ & $151 \pm 0.013^{a}$ \\
\hline PCT & $118 \pm 0.018^{\mathrm{b}}$ & $267 \pm 0.002^{\mathrm{b}}$ \\
\hline GT & $95 \pm 0.005^{c}$ & $250 \pm 0.003^{c}$ \\
\hline PT & $55 \pm 0.002^{d}$ & $161 \pm 0.004^{\mathrm{d}}$ \\
\hline \multicolumn{3}{|c|}{ After $10 \mathrm{~min}$. steeping } \\
\hline $\mathrm{FT}$ & $60 \pm 0.002^{\mathrm{a}}$ & $124 \pm 0.015^{a}$ \\
\hline PCT & $100 \pm 0.005^{\mathrm{b}}$ & $269 \pm 0.038^{b}$ \\
\hline GT & $93 \pm 0.006^{c}$ & $206 \pm 0.025^{c}$ \\
\hline PT & $34 \pm 0.052^{d}$ & $180 \pm 0.009^{d}$ \\
\hline \multicolumn{3}{|c|}{ After 15 min. steeping } \\
\hline FT & $56 \pm 0.008^{a}$ & $139 \pm 0.025^{a}$ \\
\hline PCT & $110 \pm 0.014^{\mathrm{b}}$ & $293 \pm 0.014^{b}$ \\
\hline GT & $107 \pm 0.012^{\mathrm{c}}$ & $195 \pm 0.003^{c}$ \\
\hline PT & $72 \pm 0.014^{d}$ & $115 \pm 0.008^{d}$ \\
\hline \multicolumn{3}{|c|}{ After $30 \mathrm{~min}$. steeping } \\
\hline FT & $73 \pm 0.002^{\mathrm{a}}$ & $118 \pm 0.004^{a}$ \\
\hline PCT & $107 \pm 0.005^{b}$ & $271 \pm 0.027^{\mathrm{b}}$ \\
\hline GT & $103 \pm 0.002^{c}$ & $247 \pm 0.009^{c}$ \\
\hline PT & $87 \pm 0.019^{d}$ & $207 \pm 0.006^{d}$ \\
\hline \multicolumn{3}{|c|}{ After $60 \mathrm{~min}$. steeping } \\
\hline $\mathrm{FT}$ & $118 \pm 0.008^{a}$ & $131 \pm 0.025^{a}$ \\
\hline PCT & $111 \pm 0.015^{b}$ & $240 \pm 0.011^{b}$ \\
\hline GT & $126 \pm 0.005^{c}$ & $275 \pm 0.019^{c}$ \\
\hline PT & $113 \pm 0.019^{d}$ & $151 \pm 0.013^{d}$ \\
\hline
\end{tabular}

PT: Powder tea; FT: Filtered tea bag; PCT: Powder Ceylon tea; GT: Goran tee (Mevlana)

TAE-tannic acid equivalents, GAE-Gallic acid equivalents. Means with different superscripts ( $a$-d) are significantly different, $p<0.05$

\subsection{In vitro evaluation of antioxidant assays}

FT [5 $\mathrm{min}(84.90 \%)$ and $15 \mathrm{~min}(83.22 \%)$, PCT [30 $\mathrm{min}$ $(83.33 \%)$ and $60 \mathrm{~min}(83 \%)]$ and GT [ $10 \mathrm{~min}(81.66 \%)]$ samples exhibited stronger free radical scavenging activity than other samples. When the DPPH radical scavenging activities of samples were examined at $200 \mu \mathrm{g} / \mathrm{mL}$ concentrations, it was determined that all samples prepared at different times showed very close free radical scavenging activity.

In this study, according to obtained FRAP values, PCT (0.19 $\mathrm{mM} \mathrm{Fe} \mathrm{F}^{+2} / \mathrm{mg}$ extract) and FT (0.18 $\mathrm{mM} \mathrm{Fe}^{+2} / \mathrm{mg}$ extract) samples obtained after $60 \mathrm{~min}$ steeping showed the strongest ferric reducing/antioxidant power activity. It was also found that the FRAP values of GT and PT samples did not change depending on the infusion time of the study.

According to the results obtained from the CUPRAC experiment, PCT and GT obtained after $5 \mathrm{~min}-60 \mathrm{~min}$ steeping were found to have higher cupric reducing antioxidant activity than the other samples. When the CUPRAC values of all samples were compared, it was found that all the samples had very close each other cupric reducing antioxidant activity. In this study, findings suggest that the steeping time did not effective on cupric reducing antioxidant activity of samples.

Table 3. Effects of steeping time on the antioxidant activity of tea samples

\begin{tabular}{|c|c|c|c|}
\hline Codes of samples & $\begin{array}{l}\text { FRAP ( } \mathrm{mM} \text { Fe } \\
+2 / \mathrm{mg} \text { extract) }\end{array}$ & $\begin{array}{l}\text { CUPRAC (mM } \\
\text { trolox } / \mathrm{mg} \\
\text { extract }\end{array}$ & $\begin{array}{l}\text { DPPH (\%) } \\
(200 \mu \mathrm{g} / \mathrm{mL})\end{array}$ \\
\hline \multicolumn{4}{|c|}{ After 5 min. steeping } \\
\hline FT & $0.03 \pm 0.01^{a}$ & $1.07 \pm 0.04^{a}$ & $84.90 \pm 0.95^{a}$ \\
\hline PCT & $0.05 \pm 0.02^{\mathrm{b} a \mathrm{a}}$ & $1.12 \pm 0.04^{b}$ & $83.33 \pm 0195^{b}$ \\
\hline GT & $0.05 \pm 0.01^{\text {cab }}$ & $1.12 \pm 0.02^{c b}$ & $84.45 \pm 0.77^{\text {ca.b }}$ \\
\hline PT & $0.05 \pm 0.01^{d, a b c}$ & $1.04 \pm 0.12^{d}$ & $79.70 \pm 0.01^{d}$ \\
\hline $\mathrm{BHA}$ & & & $83.22 \pm 0.7^{\mathrm{ebc}}$ \\
\hline \multicolumn{4}{|c|}{ After $10 \mathrm{~min}$. steeping } \\
\hline $\mathrm{FT}$ & $0.06 \pm 0.03^{a}$ & $1.07 \pm 0.01^{a}$ & $77.96 \pm 0.77^{\mathrm{a}}$ \\
\hline PCT & $0.11 \pm 0.11^{\text {b.a }}$ & $1.13 \pm 0.01^{b}$ & $79.64 \pm 2.18^{\mathrm{ba}}$ \\
\hline GT & $0.01 \pm 0.01^{\text {cab }}$ & $1.10 \pm 0.03^{c}$ & $81.66 \pm 0.19^{c}$ \\
\hline PT & $0.03 \pm 0.01^{\mathrm{d}, \mathrm{a}, \mathrm{b}, \mathrm{c}}$ & $1.07 \pm 0.02^{\text {da }}$ & $80.76 \pm 0.70^{d b c}$ \\
\hline BHA & & & $83.22 \pm 0.7^{e}$ \\
\hline \multicolumn{4}{|c|}{ After 15 min. steeping } \\
\hline FT & $0.05 \pm 0.01^{\mathrm{a}}$ & $1.05 \pm 0.01^{\text {a }}$ & $83.22 \pm 0.34^{\mathrm{a}}$ \\
\hline PCT & $0.09 \pm 0.01^{\text {ba }}$ & $1.09 \pm 0.01^{\mathrm{b}}$ & $80.76 \pm 2.18^{\mathrm{b}}$ \\
\hline GT & $0.04 \pm 0.02^{\mathrm{c}, \mathrm{ab}}$ & $1.08 \pm 0.01^{\mathrm{cb}}$ & $80.76 \pm 1.03^{c b}$ \\
\hline PT & $0.09 \pm 0.05^{d, a b c}$ & $1.04 \pm 0.01^{\text {d,a }}$ & $82.44 \pm 1.08^{\mathrm{d} a \mathrm{a}}$ \\
\hline BHA & & & $83.22 \pm 0.7^{\text {ead }}$ \\
\hline \multicolumn{4}{|c|}{ After $30 \mathrm{~min}$. steeping } \\
\hline FT & $0.05 \pm 0.02^{\mathrm{a}}$ & $1.10 \pm 0.02^{\text {a }}$ & $78.19 \pm 2.14^{\mathrm{a}}$ \\
\hline PCT & $0.09 \pm 0.01^{\text {ba }}$ & $1.10 \pm 0.02^{b}$ & $83.33 \pm 0.70^{\mathrm{b}}$ \\
\hline GT & $0.09 \pm 0.02^{c, a b}$ & $1.09 \pm 0.03^{c b}$ & $82.21 \pm 0.34^{c b}$ \\
\hline PT & $0.06 \pm 0.01^{\text {dabc }}$ & $1.06 \pm 0.05^{d a}$ & $79.53 \pm 1.7^{\text {da }}$ \\
\hline BHA & & & $83.22 \pm 0.7^{\mathrm{ebc}}$ \\
\hline \multicolumn{4}{|c|}{ After $60 \mathrm{~min}$. steeping } \\
\hline $\mathrm{FT}$ & $0.18 \pm 0.01^{\mathrm{a}}$ & $1.06 \pm 0.01^{a}$ & $76.51 \pm 1.37^{a}$ \\
\hline PCT & $0.19 \pm 0.21^{\text {b.a }}$ & $1.09 \pm 0.02^{b}$ & $83 \pm 0.51^{\text {b }}$ \\
\hline GT & $0.06 \pm 0.01^{c}$ & $1.09 \pm 0.01^{c b}$ & $81.54 \pm 1.95^{c}$ \\
\hline PT & $0.06 \pm 0.01^{d c}$ & $1.07 \pm 0.03^{\mathrm{d} a}$ & $82.66 \pm 1.27^{\mathrm{d}, \mathrm{b}, \mathrm{c}}$ \\
\hline BHA & & & $83.22 \pm 0.7^{\text {abd }}$ \\
\hline BHT & $1.1 \pm 0.12^{\mathrm{e}}$ & $5.78 \pm 0.07^{e}$ & \\
\hline
\end{tabular}

PT: Powder tea; FT: Filtered tea bag; PCT: Powder Ceylon tea; GT: Goran tee (Mevlana)

Means with different superscripts (a-e) are significantly different, $p<0.05$. FRAP:ferric reducing/antioxidant power; DPPH: 2,2-diphenyl-1-picrylhydrazyl; CUPRAC: Cupric reducing antioxidant capacity; BHA:Butylated hyroxyanisole; BHT:Butylated hyroxytoluene 


\subsection{In vitro evaluation of anticholinesterase activity}

The results for the assessment of cholinesterase inhibitory activity of samples $(500 \mu \mathrm{g} / \mathrm{mL})$ were shown in Table 4 . According to obtained results, PT [5 $\mathrm{min}$ (68.58\%), $10 \mathrm{~min}$ (66.58\%), and $60 \mathrm{~min}(62.66 \%)$ ] and FT [15 $\min (66.21 \%)$ and $30 \mathrm{~min}(66.21 \%)]$ samples showed stronger anticholinesterase activity than other samples. When the values of enzyme inhibition of all samples were compared, it was found that all the samples showed very close each other anticholinesterase activity. In this study, findings suggest that the steeping time is no significant effective on anticholinesterase activity of samples.

Table 4. Effects of steeping time on the anticholinesterase activity of tea samples

\begin{tabular}{|c|c|}
\hline Codes of samples & Enzyme inhibition (\%) $(500 \mu \mathrm{g} / \mathrm{mL}$ \\
\hline \multicolumn{2}{|l|}{ After $5 \mathrm{~min}$. steeping } \\
\hline FT & $62.22 \pm 2.6^{\mathrm{a}}$ \\
\hline PCT & $48.57 \pm 0.26^{b}$ \\
\hline GT & $58.29 \pm 0.97^{\mathrm{c}}$ \\
\hline PT & $68.58 \pm 0.35^{d}$ \\
\hline \multicolumn{2}{|l|}{ After $10 \mathrm{~min}$. steeping } \\
\hline $\mathrm{FT}$ & $55.86 \pm 1.09^{a}$ \\
\hline PCT & $56.86 \pm 0.33^{\mathrm{b} . a}$ \\
\hline GT & $60.60 \pm 0.18^{c}$ \\
\hline PT & $66.58 \pm 2.29^{d}$ \\
\hline \multicolumn{2}{|l|}{ After $15 \mathrm{~min}$. steeping } \\
\hline FT & $66.21 \pm 0.62^{\mathrm{a}}$ \\
\hline PCT & $58.65 \pm 0.95^{b}$ \\
\hline GT & $63.78 \pm 0.44^{c}$ \\
\hline PT & $63.47 \pm 0.35^{d . c}$ \\
\hline \multicolumn{2}{|l|}{ After 30 min. steeping } \\
\hline $\mathrm{FT}$ & $66.21 \pm 1.31^{\mathrm{a}}$ \\
\hline PCT & $59.16 \pm 0.26^{b}$ \\
\hline GT & $60.47 \pm 0.18^{\mathrm{cb}}$ \\
\hline PT & $57.23 \pm 0.18^{d}$ \\
\hline \multicolumn{2}{|l|}{ After $60 \mathrm{~min}$. steeping } \\
\hline FT & $58.48 \pm 0.87^{\mathrm{a}}$ \\
\hline PCT & $54.68 \pm 1.67^{\mathrm{b}}$ \\
\hline GT & $59.41 \pm 2.02^{\mathrm{ca}}$ \\
\hline PT & $62.66 \pm 0.79^{d}$ \\
\hline Galantamine $(200 \mathrm{\mu g} / \mathrm{mL})$ & $98.12 \pm 0.001^{e}$ \\
\hline
\end{tabular}

PT: Powder tea; FT: Filtered tea bag; PCT: Powder Ceylon tea; GT: Goran tee (Mevlana)

Means with different superscripts ( $a-e$ ) are significantly different, $p<0.05$

\section{DISCUSSION}

Because of antioxidants, products have preventive potential against a large number of diseases; antioxidants in food, beverages and herbal extracts have been extensively studied. Many studies have shown that the biological activity of tea may be due to polyphenols (11-13). Polyphenol compounds are secondary metabolites found in medicinal plants, vegetables, fruits and various beverages such as fruit juices, wine and tea (14-17). In this context, there are many reports describing the biological activity and polyphenol content of black teas. Studies have shown that black tea contains high amounts of polyphenol compounds and has strong antioxidant activity (18-20). In this study, it was confirmed that four different black teas commercially valuable in Turkey is a good source of these components. Previous studies have shown that antioxidant capacity and total polyphenol content in green tea extracts are related to extraction time (21-23). However, there are limited studies on the effect of infusion time on the extraction of phenolic compounds in tea and on the biological activities of tea.

Therefore, we have studied the effects of the time of infusion on phenolic content and biological activities of the samples obtained from different teas. It has been found that the time of the infusion was important in the amount of phenolic contents, since the TPC values of some teas (FT, GT and PT) change at different times. However, it was determined that the increase in TPC with infusion time was not linear. The amount of tannin present in the samples did not change significantly depending on the infusion time.

It has been determined in the literature that longer infusion time leads to an increase in TPC values $(3,4)$. In our study, the TPC values of FT, GT and PT samples increased in parallel with the literature information, but there was no significant change in the TPC value of PCT sample. The antioxidant (DPPH, CUPRAC) and anticholinesterase activities of the tea samples did not show significant change due to the time of the infusion.

Theoretically, if the health benefits associated with tea consumption are due to the presence of total phenols, then it would be beneficial to have a larger quantity and would support the longer brewing tea assumption to extract more phenols (4). In our study, in parallel with the this literature, it was determined that the amount of phenolic contents generally increased with the infusion time. According to the results obtained from this study, it was determined that four different tea have phenolic, tannins contents and biological activity very close to each other.

\section{CONCLUSION}

According to the results obtained from this study, it was determined that four different tea samples showed close biological activity each other. When we compare all the tea samples among themselves, FT sample obtained after 5 min steeping exhibited stronger DPPH radical scavenging activity than other samples. In addition, it was found that PCT samples obtained after $60 \mathrm{~min}$ and $10 \mathrm{~min}$ steeping had the highest FRAP and CUPRAC values respectively. In this study, it was found that the PCT samples obtained after 5 $\mathrm{min}, 10 \mathrm{~min}, 15 \mathrm{~min}$, and $30 \mathrm{~min}$ steeping contained higher phenolic, and tannins contents than the other samples. PT sample obtained after 5 min steeping showed the strongest anticholinesterase activity. As a results, it was determined that the amount of phenolic contents generally increased with the infusion time. It was also found that the antioxidant 
(DPPH, CUPRAC), anticholinesterase activities and tannins content of the tea samples did not show significant change due to the time of the infusion.

\section{REFERENCES}

[1] Ramdani D, Chaudhry AS, Seal CJ. Chemical composition, plant secondary metabolites, and minerals of green and black teas and the effect of different tea-to-water ratios during their extraction on the composition of their spent leaves as potential additives for ruminants. J Agric Food Chem 2013; 61: 4961-4967.

[2] Sharma V, Rao JM. A thought on the biological activities of black tea. Crit Rev Food Sci Nutr 2009; 49: 379-404.

[3] Čestić SR, Radojković MM, Cvetanović AD, Mašković P, Durovi $\mathrm{SD}$. Influence of steeping time on biological activity of black mulberry leaves tea. APTEFF 2016; 47: 1-265.

[4] McAlpine MD, Ward WE. Influence of steep time on polyphenol content and antioxidant capacity of black, green, rooibos, and herbal teas. Beverages 2016; 2(3): 2-12.

[5] Ozsoy N, Can A, Yanardağ R, Akev N. Antioxidant activity of Smilax excelsa L. leaf extracts. Food Chem 2008; 110(3): 571 583.

[6] Vijay DT, Rajendra SB. Estimation of total phenol, tannin, alkaloid and flavonoid in Hibiscus tiliaceus L. wood extracts. research and review: J Pharmacog,Phytochem 2014; 2(4): 4147.

[7] Wei F, Jinglou C, Yaling C, Yongfang L, Liming C, Lei $P$, Antioxidant, free radical scavenging, anti-inflammatoryand hepatoprotective potential of the extract from Parathelypteris nipponica (Franch.etSav.) Ching J Ethnopharmacol 2010; 130(3): 521-28.

[8] Benzie IF, Strain JJ. The ferric reducing ability of plasma (FRAP) as a measure of "antioxidant power": the FRAP assay. Anal Biochem 1996; 239(1): 70-76.

[9] Taskin D, Alkaya BD, Dölen E. HPLC-DAD/ESI-Q-TOF LC/MS Analysis of major phenolic compounds in flowers, leaves and stems of Achillea grandifolia and evaluation of their individual antioxidant properties. Chiang Mai J Sci 2017;44(3):1-12.

[10] Ellman GL, Courtney KD, Andress V, Featherstone RM. A new and rapid colorimetric determination of acetylcholinesterase activity. Biochem Pharmacol 1961;7: 88-95.
[11] Nikniaz Z, Mahdavi R, Ghaemmaghami SJ, Yagin NL, Nikniaz L. Effect of different brewing times on antioxidant activity and polyphenol content of loosely packed and bagged black teas (Camellia sinensis L.). AJP 2016;6(3):313-321.

[12] Nihal M, Ahmad N, Mukhtar H, Wood GS. Antiproliferative and proapoptotic effects of - epigallocatechin-3-gallate on human melanoma: Possible implications for the chemoprevention of melanoma. Int J Cancer 2005; 114: 513-521.

[13] Karakaya S, Kavas A. Antimutagenic activities of some foods. J Sci Food Agri 1999; 79: 237-242.

[14] Scalbert A, Johnson IT, Saltmarsh M. Polyphenols: Antioxidants and beyond. Am J Clin Nutr 2005; 81: 215-217.

[15] Mahdavi R, Nikniaz Z, Rafraf M, Jouyban A. Determination and comparison of the total polyphenol contents of fresh and commercial fruit juices. BFJ 2011; 113(6): 744-752.

[16] Tsao R, Yang R. Optimization of a new mobile phase to know the complex and real polyphenolic composition: towards a total phenolic index using high-performance liquid chromatography. J Chromatgr 2003; 1018: 29-40.

[17] Singleton VL, Joseph A, Rossi, JRJA. Colorimetry of total phenolics with phosphomolybdic-phosphotungstic acid reagents. Am J Enol Vitic 1965; 16: 144-158.

[18] Yashin A, Yashin Y, Nemzer B. Determination of antioxidant activity in tea extracts, and their total antioxidant content. Am J Biomed Sci 2011; 3: 322-335.

[19] Khokhar S, Magnusdottir SGM. Total phenol, catechin, and caffeine contents of teas commonly consumed in the United Kingdom. J Agri Food Chem 2002; 50: 565-570.

[20] Chan EWC, Lim YY, Chew YL. Antioxidant activity of Camellia sinensis leaves and tea from a lowland plantation in Malaysia. Food Chem 2007; 102:1214-1222.

[21] Cheong WJ, Park MH, Kang GW, Ko JH, Seo YJ. Determination of catechin compounds in Korean green tea Infusions under various extraction conditions by high performance liquid chromatography. Bull Korean Chem 2005; 26: 747-754.

[22] Lachman J, Hosnedl V, Pivec V, Orsak M. Polyphenol content in green, black and oolong tea (Camellia sinensis/L./kuntze) infusions in different times of tea maceration. Scientia Agriculturae Bohemica 2003; 34: 22-28.

[23] Armoskaite V, Ramanauskiene K, Maruska A, Razukas A, Dagilyte $A$, Baranauskas $A$, Briedis $V$. The analysis of quality and antioxidant activity of green tea extracts. J Med Plants Res 2011; 5: 811-816.

How to cite this article: Taskin T, Levent M, Sahin T. Investigation of the Effects of Biological Activity and Steeping Time of Four Different Black Teas Commercially Valuable in Turkey. Clin Exp Health Sci 2019; 9: 283-287. DOI: 10.33808/clinexphealthsci.516099 